\title{
Classification, Pathophysiology, Diagnosis and Management of Diabetes Mellitus
}

\author{
Habtamu Wondifraw Baynest
}

University of Gondar, Ethopia

\begin{abstract}
Diabetes Mellitus (DM) is a metabolic disorder characterized by the presence of chronic hyperglycemia either immune-mediated (Type 1 diabetes), insulin resistance (Type 2), gestational or others (environment, genetic defects, infections, and certain drugs). According to International Diabetes Federation Report of 2011 an estimated 366 million people had DM, by 2030 this number is estimated to almost around 552 million. There are different approaches to diagnose diabetes among individuals, The 1997 ADA recommendations for diagnosis of DM focus on fasting Plasma Glucose (FPG), while WHO focuses on Oral Glucose Tolerance Test (OGTT). This is importance for regular follow-up of diabetic patients with the health care provider is of great significance in averting any long term complications.
\end{abstract}

Keywords: Diabetes mellitus; Epidemiology; Diagnosis; Glycemic management

\begin{abstract}
Abbreviations: DM: Diabetes Mellitus; FPG: Fasting Plasma Glucose; GAD: Glutamic Acid Decarboxylase; GDM: Gestational Diabetes Mellitus; HDL-cholesterol: High Density Lipoprotein cholesterol; HLA: Human Leucoid Antigen; IDDM: Insulin Dependent Diabetes Mellitus; IFG: Impaired Fasting Glucose; IGH: Increased Glycated Hemoglobin; IGT: Impaired Glucose Test; NIDDM: NonInsulin Dependent Diabetes Mellitus; OGTT: Oral Glucose Tolerance Test
\end{abstract}

\section{Introduction}

Diabetes Mellitus (DM) is a metabolic disorder characterized by the presence of chronic hyperglycemia accompanied by greater or lesser impairment in the metabolism of carbohydrates, lipids and proteins. $\mathrm{DM}$ is probably one of the oldest diseases known to man. It was first reported in Egyptian manuscript about 3000 years ago [1]. In 1936, the distinction between type 1 and type $2 \mathrm{DM}$ was clearly made [2]. Type $2 \mathrm{DM}$ was first described as a component of metabolic syndrome in $1988[3]$.

The origin and etiology of DM can vary greatly but always include defects in either insulin secretion or response or in both at some point in the course of disease. Mostly patients with diabetes mellitus have either type 1 diabetes (which is immune-mediated or idiopathic) Type $2 \mathrm{DM}$ (formerly known as non-insulin dependent DM) is the most common form of DM characterized by hyperglycemia, insulin resistance, and relative insulin deficiency [4].

Type $2 \mathrm{DM}$ results from interaction between genetic, environmental and behavioral risk factors [5,6]. Diabetes also can be related to the gestational hormonal environment, genetic defects, other infections, and certain drugs [7].

\section{Epidemiology}

The application of epidemiology to the study of DM has provided valuable information on several aspects of this disease such as its natural history, prevalence, incidence, morbidity and mortality in diverse populations around the world. Identification of the cause of the disease and the possible preventive measures that could be instituted to arrest or delay the onset of this disease which has reached epidemic proportions in both the developed and the developing nations [8].
Unfortunately, the improvement in outcomes for individual patients with diabetes has not resulted in similar improvements from the public health perspective.

The worldwide prevalence of diabetes has continued to increase dramatically. Globally, as of 2011, an estimated 366 million people had DM, with type 2 making up about $90 \%$ of the cases $[9,10]$. The number of people with type $2 \mathrm{DM}$ is increasing in every country with $80 \%$ of people with DM living in low- and middle-income countries. Literature search has shown that there are few data available on the prevalence of type $2 \mathrm{DM}$ in Africa as a whole. Studies examining data trends within Africa point to evidence of adramatic increase in prevalence in both rural and urban setting, and affecting both gender proportionally [11]. According to the World Fact book report in 2008, in Africa the prevalence of diabetes mellitus was $3.2 \%$, and 40,895 persons $(2.0 \%)$ was in Ethiopia [12].

Although T2DM is widely diagnosed in adults, its frequency has markedly increased in the pediatric age group over the past two decades. Depending on the population studied, T2DM now represents $8-45 \%$ of all new cases of diabetes reported among children and escent [13]. The prevalence of T2DM in the pediatric population is higher among girls than boys, just as it is higher among women than men [14].

The mean age of onset of T2DM is 12-16 years; this period coincides with puberty, when a physiologic state of insulin resistance develops. In this physiologic state, T2DM develops only if inadequate beta-cell function is associated with other risk factors (e.g. obesity) [15].

Certain literatures also stated that T1DM is the most common form of diabetes in most part of the world. Wide variations exist between the

*Corresponding author: Habtamu Wondifraw Baynes, Lecturer Clinical Chemistry, University of Gondar, Gondar, Amhara 196, Ethiopia, Tel: +251910818289; E-mail: habtamuw97@gmail.com

Received March 16, 2015; Accepted April 27, 2015; Published April 30, 2015

Citation: Baynes HW (2015) Classification, Pathophysiology, Diagnosis and Management of Diabetes Mellitus. J Diabetes Metab 6: 541. doi:10.4172/21556156.1000541

Copyright: @ 2015 Baynes HW. This is an open-access article distributed under the terms of the Creative Commons Attribution License, which permits unrestricted use, distribution, and reproduction in any medium, provided the original author and source are credited. 
Citation: Baynes HW (2015) Classification, Pathophysiology, Diagnosis and Management of Diabetes Mellitus. J Diabetes Metab 6: 541. doi:10.4172/2155-6156.1000541

Page 2 of 9

incidence rates of different populations, incidence is lowest in China (0.1 per 105 per year) and highest in Finland (37 per 105 per year).In most populations girls and boys are equally affected. In general, the incidence increases with age, the incidence peak is at puberty. After the pubertal years, the incidence rate significantly drops in young women, but remains relatively high in young adult males up to the age 29-35 years [16].

Presently as many as $50 \%$ of people with diabetes are undiagnosed. Since therapeutic intervention can reduce complications of the disease, there is a need to detect diabetes early in its course. The risk of developing Type 2 diabetes increases with age, obesity, and lack of physical activity. Its incidence is increasing rapidly, and by 2030 this number is estimated to almost around 552 million [17,5]. Diabetes mellitus occurs throughout the world, but is more common (especially type 2) in the more developed countries, where the majority of patients are aged between 45 and 64 years. The greatest increase in prevalence is, however, expected to occur in Asia and Africa, where most patients will probably be found by 2030 [5] (Table 1). It is projected that the latter will equal or even exceed the former in developing nations, thus culminating in a double burden as a result of the current trend of transition from communicable to non-communicable diseases [18].

\section{Classification of Diabetes Mellitus}

If any characteristic can define the new intentions for DM classification, it is the intention to consolidate etiological views concerning DM. The old and confusing terms of insulin-dependent (IDDM) or non-insulin-dependent (NIDDM) which were proposed by WHO in1980 and 1985 have disappeared and the terms of new classification system identifies four types of diabetes mellitus: type 1, type 2, "other specific types" and gestational diabetes [6]. The etiologic classifications of diabetes mellitus are listed in (Table 2).

\section{Type 1 diabetes mellitus}

Type 1 diabetes mellitus (juvenile diabetes) is characterized by beta cell destruction caused by an autoimmune process, usually leading to absolute insulin deficiency [20]. Type 1 is usually characterized by the presence of anti-glutamic acid decarboxylase, islet cell or insulin antibodies which identify the autoimmune processes that lead to beta cell destruction. Eventually, all type1 diabetic patients will require insulin therapy to maintain normglycemia.

\section{Type 2 diabetes mellitus}

The relative importance of defects in insulin secretion or in the peripheral action of the hormone in the occurrence of DM2 has been and will continue to be cause for discussion. DM2 comprises $80 \%$ to $90 \%$ of all cases of DM. Most individuals with Type 2 diabetes exhibit intra-abdominal (visceral) obesity, which is closely related to the presence of insulin resistance. In addition, hypertension and dyslipidemia (high triglyceride and low HDL-cholesterol levels; postprandial hyperlipidemia) often are present in these individuals. This is the most common form of diabetes mellitus and is highly associated with a family history of diabetes, older age, obesity and lack of exercise. It is more common in women, especially women with a history of gestational diabetes, and in Blacks, Hispanics and Native Americans.

\section{Gestational Diabetes Mellitus (GDM)}

Gestational diabetes mellitus is an operational classification (rather than a pathophysiologic condition) identifying women who develop diabetes mellitus during gestation. Women who develop Type 1 diabetes mellitus during pregnancy and women with undiagnosed asymptomatic Type 2 diabetes mellitus that is discovered during pregnancy are classified with Gestational Diabetes Mellitus (GDM). In most women who develop GDM; the disorder has its onset in the third trimester of pregnancy.

\section{Other specific type (Monogenic diabetes)}

Types of diabetes mellitus of various known etiologies are grouped together to form the classification called "Other Specific Types". This group includes persons with genetic defects of beta-cell function (this type of diabetes was formerly called MODY or maturity-onset diabetes in youth) or with defects of insulin action; persons with diseases of the exocrine pancreas, such as pancreatitis or cystic fibrosis; persons with dysfunction associated with other endocrinopathies (e.g. acromegaly); and persons with pancreatic dysfunction caused by drugs, chemicals or infections and they comprise less than $10 \%$ of DM cases.

\section{Clinical Features of Diabetes Mellitus}

\section{General symptoms}

Most of the symptoms are similar in both types of diabetes but they vary in their degree and develop more rapidly in type 1 diabetes and more typical.

\section{Clinical features of type I diabetes}

Some of the symptoms include weight loss, polyurea, polydipsia, polyphagia, constipation fatigue, cramps, blurred vision, and candidiasis [21]. Long lasting type $1 \mathrm{DM}$ patients may susceptible to microvascular complications; [22-24] and macrovascular disease (coronary artery, heart, and peripheral vascular diseases) [25].

\section{Clinical features of Type II diabetes}

Most cases are diagnosed because of complications or incidentally.

\begin{tabular}{|c|c|c|c|c|}
\hline \multicolumn{3}{|c|}{2000} & \multicolumn{2}{|c|}{2030} \\
\hline Ranking & Country & $\begin{array}{c}\text { People with } \\
\text { diabetes (millions) }\end{array}$ & Country & $\begin{array}{c}\text { People with } \\
\text { diabetes (millions) }\end{array}$ \\
\hline $\begin{array}{c}1 \\
2 \\
3 \\
4 \\
5 \\
6 \\
7 \\
8 \\
9 \\
10\end{array}$ & $\begin{array}{l}\text { India } \\
\text { China } \\
\text { U.S. } \\
\text { Indonesia } \\
\text { Japan } \\
\text { Pakistan } \\
\text { Russian Federation } \\
\text { Brazil } \\
\text { Italy } \\
\text { Bangladesh }\end{array}$ & $\begin{array}{l}31.7 \\
20.8 \\
17.7 \\
8.4 \\
6.8 \\
5.2 \\
4.6 \\
4.6 \\
4.3 \\
3.2\end{array}$ & $\begin{array}{c}\text { India } \\
\text { China } \\
\text { U.S. } \\
\text { Indonesia } \\
\text { Pakistan } \\
\text { Brazil } \\
\text { Bangladesh } \\
\text { Japan } \\
\text { Philippines } \\
\text { Egypt }\end{array}$ & $\begin{array}{l}79.4 \\
42.3 \\
30.3 \\
21.3 \\
13.9 \\
11.3 \\
11.1 \\
8.9 \\
7.8 \\
6.7\end{array}$ \\
\hline
\end{tabular}

Table 1: List of countries with the highest numbers of estimated cases of diabetes for 2000 and 2030. Adapted from Wild S [5]. 
Citation: Baynes HW (2015) Classification, Pathophysiology, Diagnosis and Management of Diabetes Mellitus. J Diabetes Metab 6: 541. doi:10.4172/2155-6156.1000541

\section{I. type 1Diabetes mellitus}

A. Autoimmune

B. Idiopathic

II. type 2 Diabetes mellitus

Ranges from relative insulin deficiency to disorders

of insulin secretion and insulin resistance

III. Other specific types of diabetes mellitus

A. Genetic defects in $\beta$-cell function

1. Chromosome 12, HNF-1a (MODY 3)

2. Chromosome 7 , glycosidase (MODY 2)

3. Chromosome 20, HNF-4a (MODY 1)

4. Mitochondrial DNA

5. Monogenic diabetes

B. Genetic defects in insulin action

1. Type A insulin resistance

2. Leprechaunism

3. Rabson-Mendenhall syndrome

4. Lipotrophic diabetes

C. Disease of the exocrine pancreas

1. Pancreatitis

2. Pancreatectomy/trauma

3. Neoplasia

4. Cystic fibrosis

5. Hemochromatosis

6. Fibrocalcific pancreatopathy

D. Endocrinopathies

1. Acromegaly

2. Cushing syndrome

3. Glucagonoma

4. Pheochromocytoma

5. Hyperthyroidism

6. Somatostatinoma

7. Aldosteronoma

i. Pharmacologically or chemically induced

1. Vacor

2. Pentamidine
3. Nicotinic acid

4. Glucocorticoids

5. Thyroid hormones

6. Diazoxide

7. $\beta$-adrenergic agonists

8. Tiazides

9. Dilantin

10. $\alpha$ interferon

ii. Infections

1. Congenital rubeola

2. Cytomegalovirus

iii. Infrequent forms of autoimmune diabetes

1. Stiff-man syndrome)

2. Antibodies against insulin receptors

iv. Other syndromes occasionally associated with diabetes

1. Down syndrome

2. Klinefelter syndrome

3. Turner syndrome

4. Wolfram syndrome

5. Friedreich ataxia

6. Huntington's chorea

7. Lawrence-Moon-Biedel syndrome

8. Myotonic dystrophy

9. Porphyria

10. Prader-Willi syndrome

V. Gestational diabetes mellitus

Occurs in mostly in women during gestation.

Table 2: Etiologic Classification of Diabetes Mellitus. Adapted from WHO and ADA [6,19].

\begin{tabular}{|c|c|c|c|}
\hline Characteristic & Type 1 & Type 2 & Monogenic \\
\hline Genetics & Polygenic & Polygenic & Monogenic \\
\hline $\begin{array}{l}\text { Age of onset } \\
\text { Clinical presentation }\end{array}$ & $\begin{array}{c}6 \text { months to young adulthood } \\
\text { Most often acute, rapid }\end{array}$ & $\begin{array}{l}\text { Usually pubertal (or later) } \\
\text { Variable; from slow, mild (often } \\
\text { insidious) to severe }\end{array}$ & $\begin{array}{c}\text { Often post pubertal except } \\
\text { Glucokinase and neonatal diabetes } \\
\text { Variable (may be incidental in } \\
\text { glucokinase) }\end{array}$ \\
\hline $\begin{array}{l}\text { Associations } \\
\text { Autoimmunity } \\
\text { Ketosis }\end{array}$ & $\begin{array}{c}\text { Yes } \\
\text { Common } \\
\text { Population }\end{array}$ & $\begin{array}{c}\text { No } \\
\text { Uncommon } \\
\text { Increased frequency }\end{array}$ & $\begin{array}{c}\text { No } \\
\text { Common in neonatal diabetes, rare in } \\
\text { other forms } \\
\text { Population frequency }\end{array}$ \\
\hline $\begin{array}{c}\text { Obesity } \\
\text { Acanthosis nigricans } \\
\text { Frequency } \\
\text { (\% of all diabetes } \\
\text { in young people) } \\
\text { Parent with diabetes }\end{array}$ & $\begin{array}{c}\text { No } \\
\text { Usually } 90 \%+ \\
2-4 \%\end{array}$ & $\begin{array}{c}\text { Yes } \\
\text { Most countries } \\
80 \%\end{array}$ & $\begin{array}{l}\text { No } \\
1-3 \% \\
90 \%\end{array}$ \\
\hline
\end{tabular}

Table 3: Clinical characteristics of type 1 diabetes, type 2 diabetes and monogenic diabetes in children and adolescents. Adapted from Craig ME [29].

Carries a high risk of large vessel atherosclerosis commonly associated with hypertension, hyperlipidaemia and obesity. Most patients with type 2 diabetes die from cardiovascular complications and end stage renal disease. Geographical variation can contribute in the magnitude of the problems and to overall morbidity and mortality [26-28] (Table 3).

\section{Pathogenesis and Pathophysiology of Diabetes Mellitus}

There is a direct link between hyperglycemia and physiological \& behavioral responses. Whenever there is hyperglycemia, the brain recognizes it and send a message through nerve impulses to pancreas and other organs to decrease its effect [30].

\section{Type 1 diabetes mellitus}

Type 1 Diabetes is characterized by autoimmune destruction of insulin producing cells in the pancreas by CD4+ and CD8+ T cells and macrophages infiltrating the islets [31]. Several features characterize type 1 diabetes mellitus as an autoimmune disease [32]:

1. Presence of immuno-competent and accessory cells in infiltrated pancreatic islets;

2. Association of susceptibility to disease with the class II (immune response) genes of the major histocompatibility complex (MHC human leucocyte antigens HLA);

3. Presence of islet cell specific autoantibodies; 
Citation: Baynes HW (2015) Classification, Pathophysiology, Diagnosis and Management of Diabetes Mellitus. J Diabetes Metab 6: 541. doi:10.4172/2155-6156.1000541

Page 4 of 9

4. Alterations of $\mathrm{T}$ cell mediated immunoregulation, in particular in $\mathrm{CD} 4+\mathrm{T}$ cell compartment;

5. The involvement of monokines and TH1 cells producing interleukins in the disease process;

6. Response to immunotherapy and;

7. Frequent occurrence of other organ specific auto- immune diseases in affected individuals or in their family members.

Approximately $85 \%$ of patients have circulating islet cell antibodies, and the majorities also have detectable anti-insulin antibodies before receiving insulin therapy. Most islet cell antibodies are directed against glutamic acid decarboxylase (GAD) within pancreatic B cells [33].

The autoimmune destruction of pancreatic $\beta$-cells, leads to a deficiency of insulin secretion which results in the metabolic derangements associated with T1DM. In addition to the loss of insulin secretion, the function of pancreatic a-cells is also abnormal and there is excessive secretion of glucagons in T1DM patients. Normally, hyperglycemia leads to reduced glucagons secretion, however, in patients with T1DM, glucagons secretion is not suppressed by hyperglycemia [34]. The resultant inappropriately elevated glucagons levels exacerbate the metabolic defects due to insulin defi-ciency. Although insulin deficiency is the primary defect in T1DM, there is also a defect in the administration of insulin. Deficiency in insulin leads to uncontrolled lipolysis and elevated levels of free fatty acids in the plasma, which suppresses glucose metabolism in peripheral tissues such as skeletal muscle [34]. This impairs glucose utilization and insulin deficiency also decreases the expression of a number of genes necessary for target tissues to respond normally to insulin such as glucokinase in liver and the GLUT 4 class of glucose transporters in adipose tissue [34] explained that the major metabolic derangements, which result from insulin deficiency in T1DM are impaired glucose, lipid and protein metabolism.

\section{Type 2 diabetes mellitus}

In type 2 diabetes these mechanisms break down, with the consequence that the two main pathological defects in type 2 diabetes are impaired insulin secretion through a dysfunction of the pancreatic $\beta$-cell, and impaired insulin action through insulin resistance [35]. In situations where resistance to insulin predominates, the mass of $\beta$-cells undergoes a transformation capable of increasing the insulin supply and compensating for the excessive and anomalous demand. In absolute terms, the plasma insulin concentration (both fasting and meal stimulated) usually is increased, although "relative" to the severity of insulin resistance, the plasma insulin concentration is insufficient to maintain normal glucose homeostasis. Keeping in mind the intimate relationship between the secretion of insulin and the sensitivity of hormone action in the complicated control of glucose homeostasis, it is practically impossible to separate the contribution of each to the etiopathogenesis of DM2 [20].

Insulin resistance and hyperinsulinemia eventually lead to impaired glucose tolerance [36]. Except for maturity onset diabetes of the young (MODY), the mode of inheritance for type 2 diabetes mellitus is unclear. MODY, inherited as an autosomal dominant trait, may result from mutations in glucokinase gene on chromosome 7p. MODY is defined as hyperglycemia diagnosed before the age of twenty-five years and treatable for over five years without insulin in cases where islet cell antibodies (ICA) are negative [26].

\section{Insulin resistance}

The primary events are believed to be an initial deficit in insulin secretion and in many patients relative insulin deficiency in association with peripheral insulin resistance [37]. Resistance to the action of insulin will result in impaired insulin mediated glucose uptake in the periphery (by muscle and fat), incomplete suppression of hepatic glucose output and impaired triglyceride uptake by fat. To overcome the insulin resistance, islet cells will increase the amount of insulin secreted. Endogenous glucose production is accelerated in patients with type 2 diabetes or impaired fasting glucose. Because this increase occurs in the presence of hyper insulinemia, at least in the early and intermediate disease stages, hepatic insulin resistance is the driving force of hyperglycemia of type 2 diabetes (Figure 1-7).

\section{Complications of diabetes mellitus}

1- Acute complications

1.1 Hypoglycemia

1.2 Hyperglycemic crises

Diabetes Ketoacidosis (DKA)

Hyperglycemic hyperosmolar state (HHS)

2- Chronic complications:

2.1 Micro vascular complications

2.1.1 Diabetic retinopathy

2.1.2 Diabetic nephropathy

2.1.3 Diabetic neuropathy

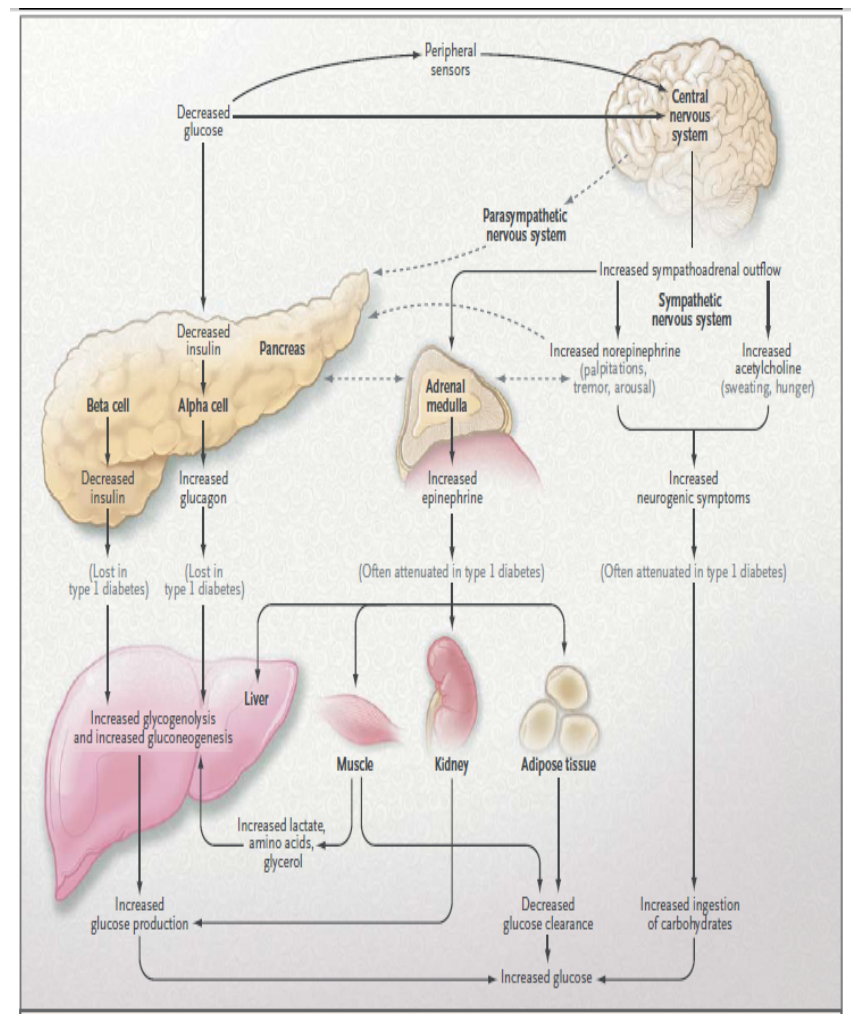

Figure 1: Physiologic and Behavioral response of hyperglycemia. Adapted from Cryer [30] 
Citation: Baynes HW (2015) Classification, Pathophysiology, Diagnosis and Management of Diabetes Mellitus. J Diabetes Metab 6: 541. doi:10.4172/2155-6156.1000541

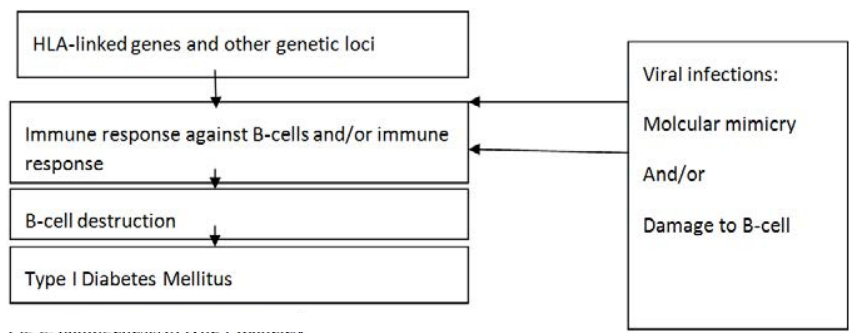

Figure 2: Pathogenesis of type 1 diabetes.

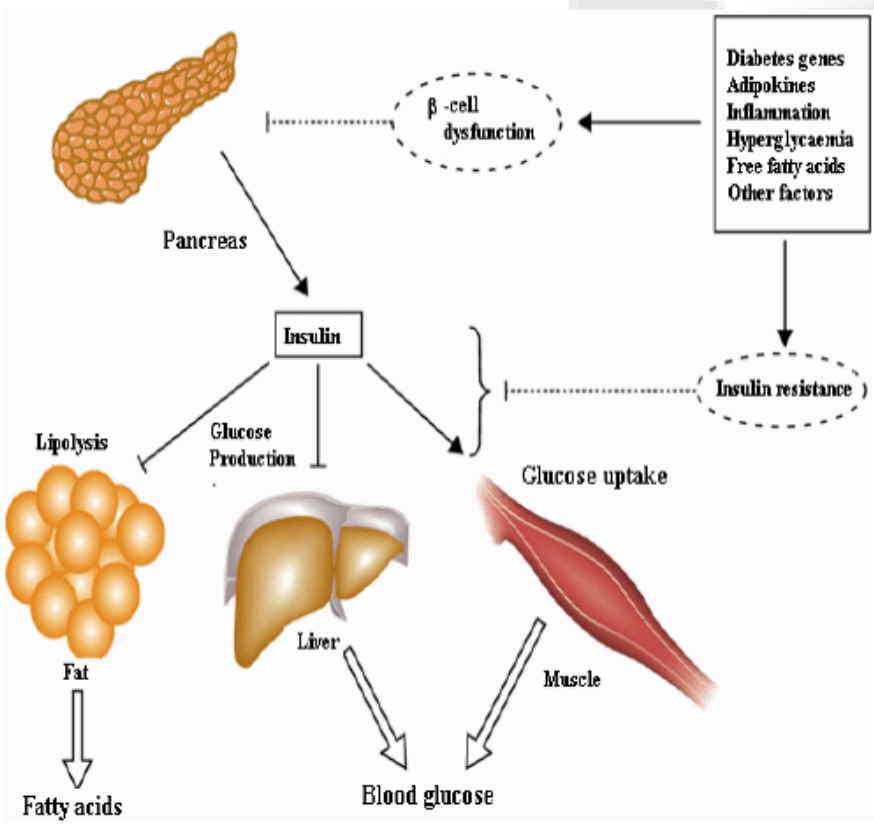

Figure 3: Pathophysiology of Hyperglycemia and increased circulating fatty acids in type 2 Diabetes. Adapted from Pittas [26].

\subsection{Macrovascular disease}

3- Other complications and associated conditions

3.1 Impaired growth and development

3.2 Associated autoimmune conditions

3.2.1 Hypothyroidism

3.2.2 Hyperthyroidism

3.2.3 Celiac disease

3.2.4 Vitiligo

3.2.5 Primary adrenal insufficiency (Addison's disease)

3.3 Lipodystrophy (lipoatrophy and lipohypertrophy)

3.4 Necrobiosis lipoidica diabeticorum

3.5 Non-alcoholic fatty liver disease

3.6 Infections seen in patients with diabetes

3.7 Limited joint mobility

3.8 Edema

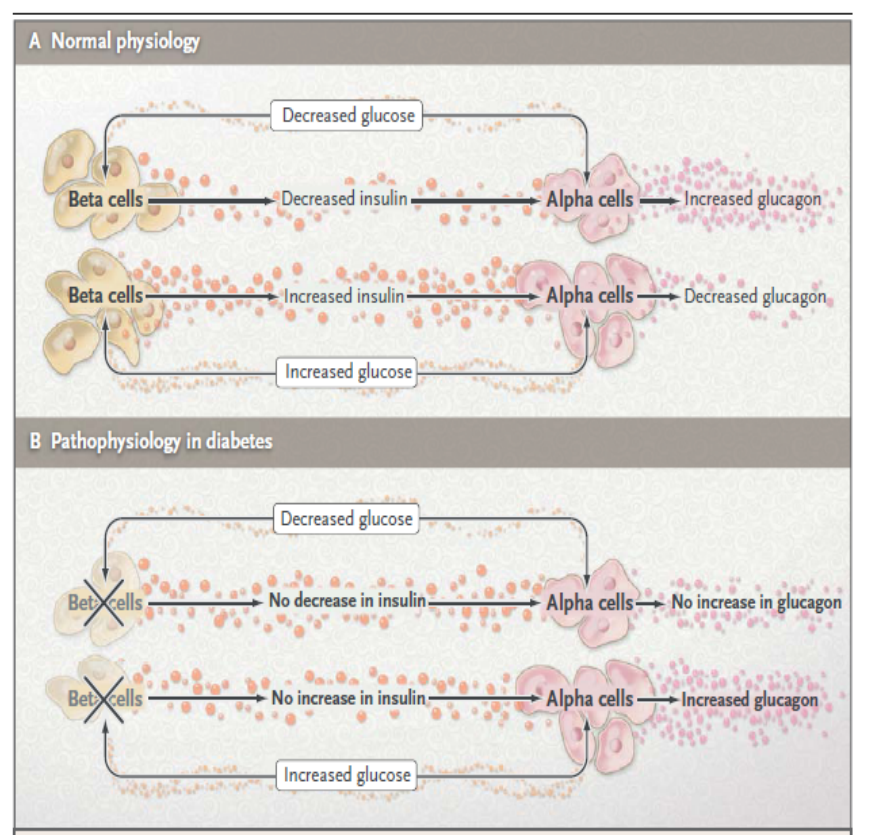

Figure 4: Panel A shows the physiological effect of a decrease in insulin coupled with a low glucose concentration in stimulating alpha-cell glucagon secretion, and Panel B shows the pathophysiological effect of beta-cell failure and the resulting loss of a decrease in insulin secretion and loss of an increase in alpha-cell glucagon secretion, despite a low glucose concentration. Adapted from Cryer [39].

\section{Diagnosis of diabetes mellitus}

The identification of patients with diabetes or pre-diabetes by screening allows for earlier intervention, with potential reductions in future complication rates, although randomized trials are lacking to definitively show benefit. The patient described in the vignette has risk factors (obesity, hypertension, and a family history of diabetes) and should be screened (Table 4) [38-40]. About $25 \%$ of patients with type 2 DM already have microvascular complications at the time of diagnosis suggesting that they have had the disease for more than 5 years at the time of diagnosis $[41,42]$. As a result there are different approaches to diagnose diabetes among individuals.

The 1997 American Diabetes Association (ADA) recommendations for diagnosis of DM focus on Fasting Plasma Glucose (FPG), while WHO focuses on the Oral Glucose Tolerance Test (OGTT) [43] (Table $5)$.

\section{Diagnosis of both types of diabetes}

\section{Random plasma test}

- The simplest test and doesn't require fasting before taking the test.

- If 200 or more than $200 \mathrm{mg} / \mathrm{dl}$ of blood glucose it probably indicates diabetes but has to be reconfirmed.

\section{Fasting plasma glucose test:}

- There should be eight hours fasting before taking this test. Blood glucose more than $126 \mathrm{mg} / \mathrm{dl}$ on two or more tests conducted on different days confirms a diabetes diagnosis [43]. 
Citation: Baynes HW (2015) Classification, Pathophysiology, Diagnosis and Management of Diabetes Mellitus. J Diabetes Metab 6: 541. doi:10.4172/2155-6156.1000541

Page 6 of 9

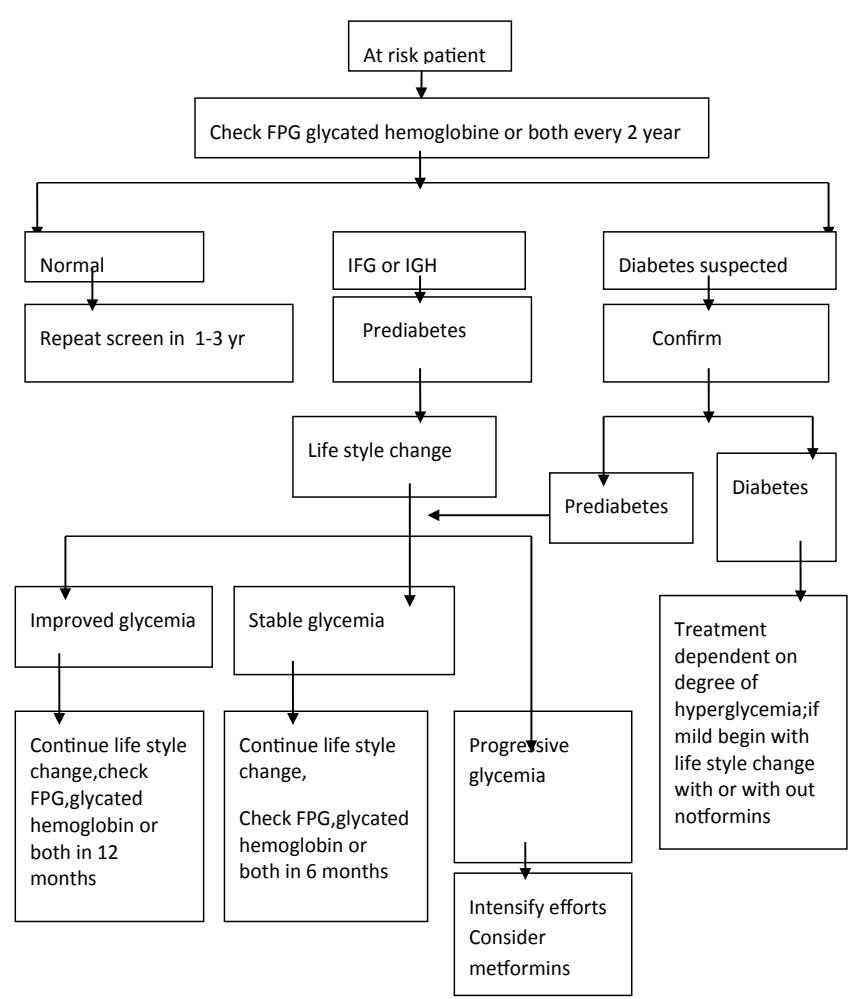

Figure 5: Suggested approach to screening patients at risk for diabetes. Adapted from Salomaa and Diabetes Care $[36,48]$

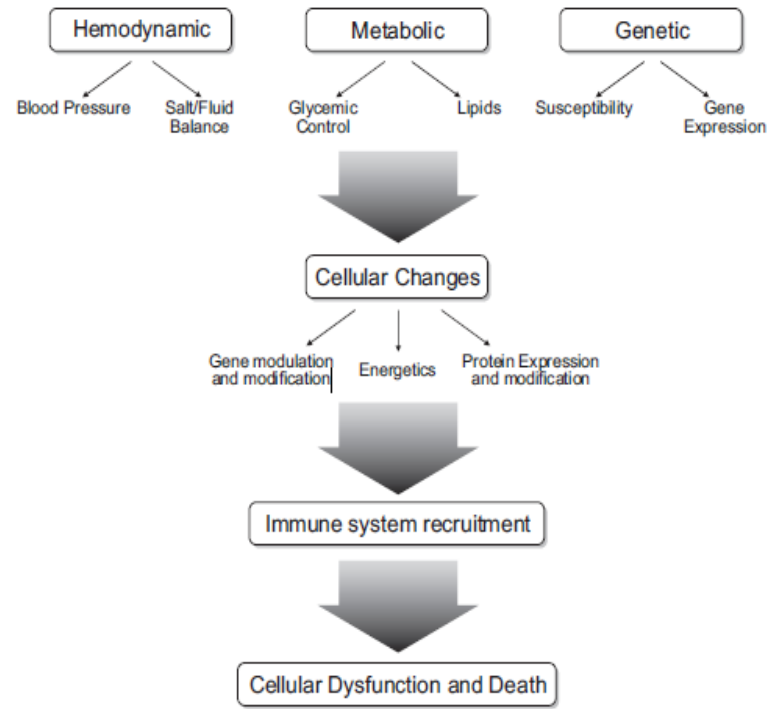

Figure 6: Schematic overview of the major areas contributing to diabetic complications. Adapted from Josephine M [40].

\section{Oral glucose tolerance test}

- When random plasma glucose test is $160-200 \mathrm{mg} / \mathrm{dl}$ and the fasting plasma test is $110-125 \mathrm{mg} / \mathrm{dl}$, then this test is conducted [7].

- This blood test evaluates body's response to glucose. This test requires fasting at least eight but not more than $16 \mathrm{hrs}$.
- Fasting glucose level is determined, and then gives $75 \mathrm{gm}$ of

glucose, $100 \mathrm{gm}$ for pregnant women. The blood is tested every 30 minutes to one hr for two or three hrs.

- This test is normal if your glucose level at two hrs is less than 140 $\mathrm{mg} / \mathrm{dl}$. A fasting level of $126 \mathrm{mg} / \mathrm{dl}$ or greater and two hour glucose level of $200 \mathrm{mg} / \mathrm{dl}$ or Higher confirms a diabetes diagnosis [43].

\section{Glycated proteins}

Proteins react spontaneously in blood with glucose to form glycated derivatives. The extent of glycation of proteins is controlled by the concentration of glucose in blood and by the number of reactive amino groups present in the protein that are accessible to glucose for reaction. All proteins with reactive sites can be glycated and the concentration of the glycated proteins that can be measured in blood is a marker for the fluctuation of blood glucose concentrations during a certain period. From a clinical diagnostic point glycated proteins with a longer life time in blood are of interest, since they reflect the exposure of these proteins to glucose for longer periods

\section{Glycated hemoglobin}

The life span of hemoglobin in vivo is 90 to120 days. During this time glycated hemoglobin A forms, being the ketoamine compound formed by combination of hemoglobin A and glucose. Several subfractions of glycated hemoglobin have been isolated. Of these, glycated hemoglobin A fraction HbAlc is of most interest serving as a retrospective indicator of the average glucose Concentration. HbAlc is recommended as an essential indicator for the monitoring of blood glucose control. The blood HbA1c $\geq 6.5 \%$ is considered as diabetes [44].

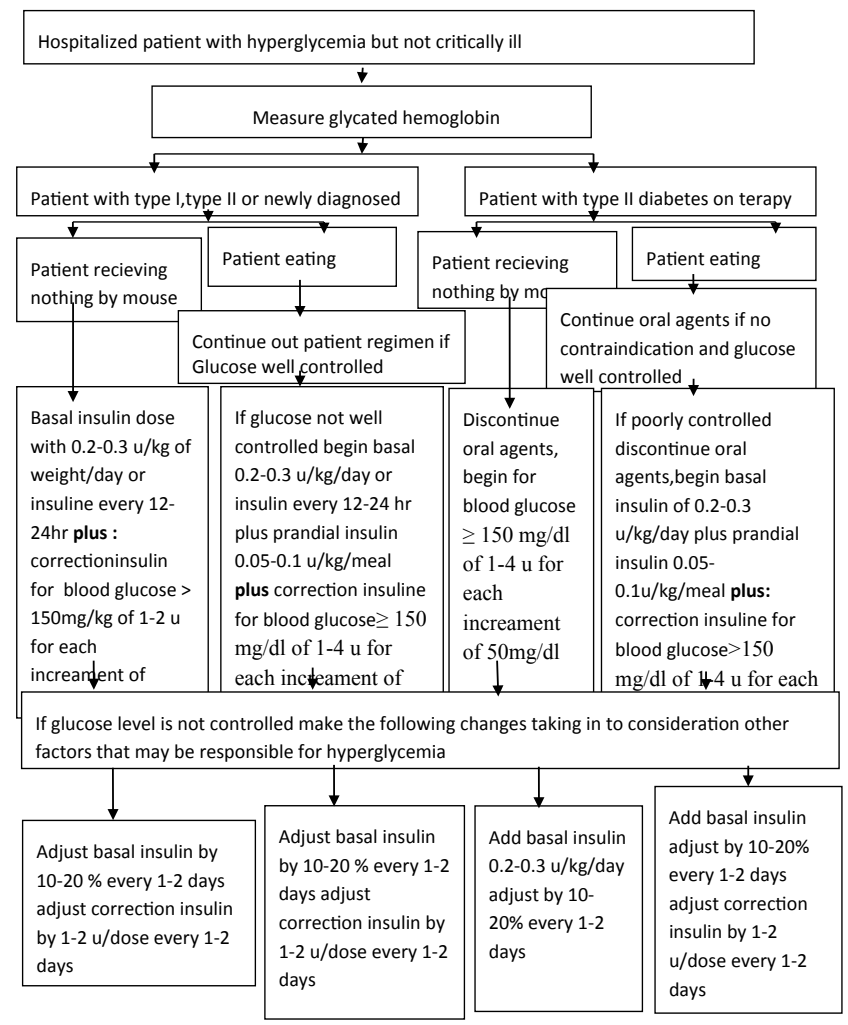

Figure 7: General management of diabetes mellitus. Adapted from Riddle $\mathrm{MC}[63]$. 


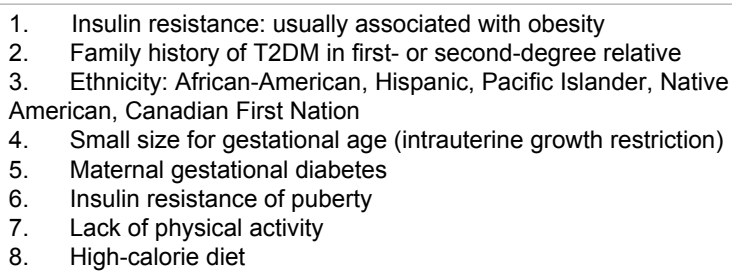

Table 4: Risk factors for T2DM in youth. Adapted from Botero D [38].

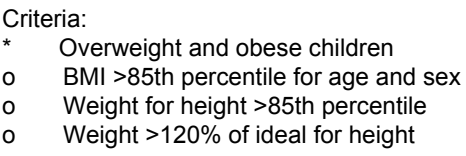

Plus any two of the following risk factors:

a. Family history of T2DM in first or second-degree relative

b. Race/Ethnicity

* Native-American * Latino

* African-American * Asian American

* Pacific Islander

c. Signs of insulin resistance or conditions associated with insulin resistance

*Acanthosis nigricans * Hypertension

Dyslipidemia

* Small for gestational age birth weight

d. Maternal history of diabetes or GDM during the child's gestation

Age of initiation: age 10 years or at onset of puberty, if puberty occurs at a younger age

Frequency: every 3 years

Preferred Test: Fasting plasma glucose

Table 5: Modified ADA Guidelines for screening children and youths for T2DM Adapted from ADA [42]

\section{Fructosamine test}

Albumin is the main component of plasma proteins. As albumin also contains free amino groups, non-enzymatic reaction with glucose in plasma occurs. Therefore glycated albumin can similarly serve as a marker to monitor blood glucose. Glycated albumin is usually taken to provide a retrospective measure of average blood glucose concentration over a period of 1 to 3 weeks. Reference interval: 205- 285 micro mol/L.

\section{Diagnosis of gestational diabetes mellitus}

At least 6 weeks after the pregnancy ends, the woman should receive an oral glucose tolerance test and be reclassified as having diabetes, normal glucose tolerance, impaired

glucose tolerance or impaired fasting glucose (Table 6). Women at high risk (positive family history, history of GDM, marked obesity, and high risk ethnic group) should be screened as soon as feasible. If the initial screening is negative, they should undergo retesting at 24-48 weeks. The diagnosis of GDM is made if two or more of the plasma glucose values in (Table 7) are met or exceeded [32].

It is unclear whether the risk of complications of diabetes differs according to whether the disease was diagnosed by means of fasting plasma glucose testing only or glycated hemoglobin testing only. Preliminary data from a large, community- based prospective cohort study suggest that the glycated hemoglobin level, which integrates fasting and postprandial glucose levels over a longer period, might be a better predictor of certain complications especially cardiovascular disease [45]. It is also not known whether the risk of diabetes differs between patients identified as having pre-diabetes by means of glycated hemoglobin testing and those identified by means of fasting plasma glucose testing. Such risks probably vary according to which test is used ultimately to make the diagnosis. Ongoing research is assessing the value of risk scores that incorporate not only glycemic measures but also other biomarkers and risk factors to estimate diabetes risk $[46,47]$.

Impaired fasting glucose (IFG) is defined as a fasting plasma glucose (FPG) level of 100 to $125 \mathrm{mg} / \mathrm{dl}$ (5.6 to $6.9 \mathrm{mmol} /$ liter). Increased glycated hemoglobin (IGH) is defined as a glycated hemoglobin level of 5.7 to $6.4 \%$. The diagnosis of diabetes is confirmed with a repeat test on a separate day or by the alternative test (i.e. glycated hemoglobin instead of FPG or vice versa) on the same day or a separate day. If the result of the repeat test is in the prediabetic range, the patient should be counseled or treated for pre-diabetes. If the result of the repeat test is entirely normal (which is unlikely), rescreening in 6 months should be considered.

\section{Glycemic Management}

One of the biggest challenges for health care providers today is addressing the continued needs and demands of individuals with chronic illnesses like diabetes [49]. The importance of regular follow-up of diabetic patients with the health care provider is of great significance in averting any long term complications. Studies have reported that strict metabolic control can delay or prevent the progression of complications associated with diabetes [50,51]. Results of large randomized trials involving patients with type 1 diabetes or newly recognized or established type 2 diabetes show that control of

\begin{tabular}{|l|l|}
\hline Time & Plasma Glucose \\
\hline Fasting & $\geq 95 \mathrm{mg} / \mathrm{dl}(5.3 \mathrm{mmol} / \mathrm{L})$ \\
\hline 1-hour & $\geq 180 \mathrm{mg} / \mathrm{dl}(10.0 \mathrm{mmol} / \mathrm{L})$ \\
\hline 2-hour & $\geq 155 \mathrm{mg} / \mathrm{dl}(8.6 \mathrm{mmol} / \mathrm{L})$ \\
\hline 3-hour & $\geq 140 \mathrm{mg} / \mathrm{dl}(7.8 \mathrm{mmol} / \mathrm{L})$ \\
\hline
\end{tabular}

Two or more values must be met or exceeded for a diagnosis of diabetes to be made. The test should be done in the morning after 8 to 14 hours fast.

Table 6: Diagnosis of gestational diabetes.

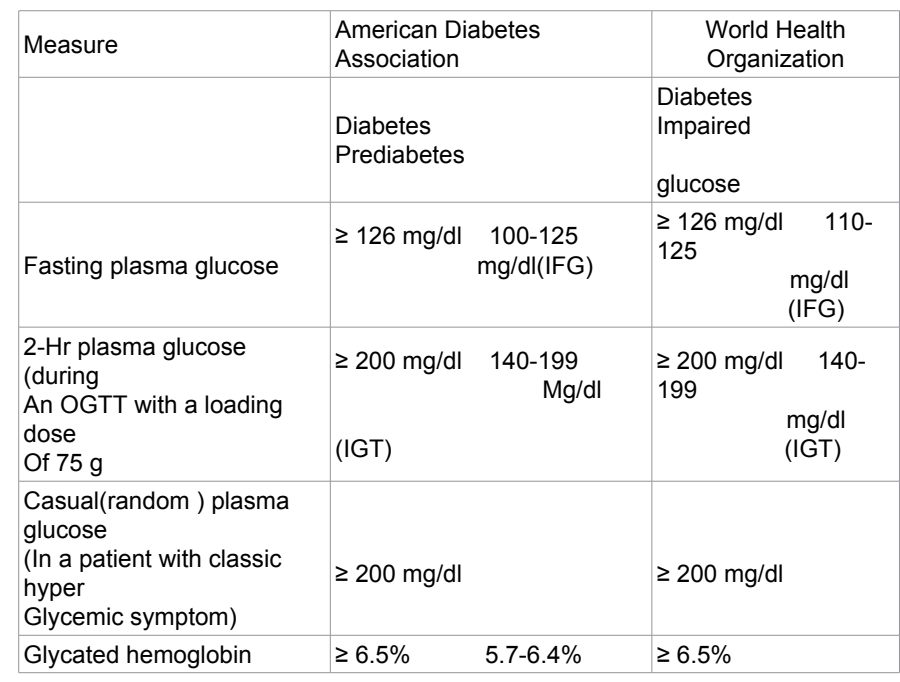

Table 7: Major diagnostic criteria for diabetes and prediabetic or at-risk states. Data are adapted from the American Diabetes Association. Adapted from Salomaa and Diabetes Care [22,23]. 
glycemia delays the onset and slows the progression of micro vascular complications, including nephropathy, retinopathy, and neuropathy [52-54]. The needs of diabetic patients are not only limited to adequate glycemic control but also correspond with preventing complications; disability limitation and rehabilitation. Some of the Indian studies revealed very poor adherence to treatment regimens due to poor attitude towards the disease and poor health literacy among the general public $[55,56]$.

Factors that should be considered in determining glycemic goals, including psychosocial limitation [57]. Glycemic targets in patients with "hypoglycemia unawareness" should be relaxed for prolonged periods, pending the potential reversal of the condition [58,59]. In patients with severe coexisting conditions that could interfere with implementation of the management strategy, the goal is prevention of clinically significant glycosuria, water and electrolyte loss, infections, and the development of non ketotic hyperosmolar coma. Insulin is indicated for type 1 diabetes as well as for type 2 diabetic patients with insulinopenia whose hyperglycemia does not respond to diet therapy either alone or combined with oral hypoglycemic drugs [60]. Controlling blood glucose with insulin has the potential to be the most effective blood glucose-lowering therapy [61]. Many patients with type 2 diabetes will eventually require insulin therapy. Since type 2 diabetes is associated with insulin resistance, insulin requirements can exceed 1 unit $/ \mathrm{kg} /$ day [62].

\section{Future Challenges}

Given that the prevalence of diabetes is high at the population level, it imposes a financial burden on both our healthcare system and the individuals living with the disease. An attempt continues to be discussed; yet as the number of undiagnosed patients continues to grow, the prevalence and impact of the disease on patient quality of life and the overall cost of diabetes to healthcare is also important.

The impact of diabetes is reaches in a crude state, it is essential to each country for implementation of preventive and curative measures. This may include restaurants to provide the caloric content of items on their menus; reduce the availability of high calorie, high-fat foods in school cafeterias; Lifestyle modification will undoubtedly play a key role in the ultimate solution to the problem of diabetes, and more definitive solutions will depend on the ability of basic science to point prevention and treatment in new directions.

\section{References}

1. Ahmed AM (2002) History of diabetes mellitus. Saudi Med J 23: 373-378.

2. Diabetes mellitus history- from ancient to modern times.

3. Patlak M (2002) New weapons to combat an ancient disease: treating diabetes. FASEB J 16: 1853.

4. Maitra A, Abbas AK (2005) Endocrine system. Robbins and Cotran Pathologic basis of disease (7thedtn). Saunders, Philadelphia. 1156-1226.

5. Wild S, Roglic G, Green A, Sicree R, King H (2004) Global prevalence of diabetes: estimates for the year 2000 and projections for 2030. Diabetes Care 27: 1047-1053

6. WHO Expert Committee on Definition (1999) Diagnosis and Classification of Diabetes Mellitus and its Complications, Geneva:1-59.

7. Guidance for Industry, Diabetes Mellitus: Developing Drugs and Therapeutic Biologics for Treatment and Prevention, U.S. Department of Health and Human Services Food and Drug Administration Center for Drug Evaluation and Research (CDER). 2008: 3

8. Zimmet PZ (1992) Kelly West Lecture 1991. Challenges in diabetes epidemiology--from West to the rest. Diabetes Care 15: 232-252.
9. Jumpup (2007) Williams Textbook of endocrinology (12thed.). Elsevier/ Saunders, Philadelphia, USA 1371-1435.

10. Chen L, Magliano DJ, Zimmet PZ (2014) The worldwide epidemiology of type 2 diabetes mellitus: present and future perspectives. Nature reviews endocrinology.

11. DMICC (2014) Genetic basis of type 1 and type2 diabetes, obesity, and their complications. Advances and emerging opportunities in diabetes research: a Strategic Planning report of the DMICC

12. Central Intelligence Agency (2008) The World Fact book: CIA.

13. [No authors listed] (2000) Type 2 diabetes in children and adolescents. American Diabetes Association. Pediatrics 105: 671-680.

14. Rosenbloom AL, Joe JR, Young RS, Winter WE (1999) Emerging epidemic of type 2 diabetes in youth. Diabetes Care 22: 345-354.

15. Grinstein G, Muzumdar R, Aponte L, Vuguin P, Saenger P, et al. (2003) Presentation and 5-year follow-up of type 2 diabetes mellitus in AfricanAmerican and Caribbean-Hispanic adolescents. Horm Res 60: 121-126.

16. Soltesz G, Patterson CC, Dahlquist G; EURODIAB Study Group (2007) Worldwide childhood type 1 diabetes incidence--what can we learn from epidemiology? Pediatr Diabetes 8 Suppl 6: 6-14

17. Global burden of diabetes. International Diabetes federation. Diabetic atlas fifth edition 201, Brussels. Yach D, Hawkes C, Gould CL, Hofman KJ (2004) The global burden of chronic diseases: overcoming impediments to prevention and control. JAMA 291: 2616-2622.

18. American Diabetes Association (1998) Report of the expert committee on the diagnosis and classification of diabetes mellitus. Diabetes Care. 21: S5-S19.

19. Mayfield J (1998) Diagnosis and classification of diabetes mellitus: new criteria Am Fam Physician 58: 1355-1362, 1369-70

20. Kumar PJ, Clark M (2002) Textbook of Clinical Medicine. Pub: Saunders London, UK. 1099-1121.

21. Bearse MA Jr, Han Y, Schneck ME, Barez S, Jacobsen C, et al. (2004) Local multifocal oscillatory potential abnormalities in diabetes and early diabetic retinopathy. Invest Ophthalmol Vis Sci 45: 3259-3265.

22. Hove MN, Kristensen JK, Lauritzen T, Bek T (2004) The prevalence of retinopathy in an unselected population of type 2 diabetes patients from Arhus County, Denmark. Acta Ophthalmol Scand 82: 443-448.

23. Seki M, Tanaka T, Nawa H, Usui T, Fukuchi T, et al. (2004) Involvement of brain-derived neurotrophic factor in early retinal neuropathy of streptozotocininduced diabetes in rats: therapeutic potential of brain-derived neurotrophic factors for dopaminergic amacrine cells. Diabetes 53: 2412-2419.

24. Saely CH, Aczel S, Marte T, et al. (2004) Cardiovascular complications in type 2 diabetes mellitus depend on the coronary angiographic state rather than on the diabetes state. Diabetologia 47: 145-146.

25. Pittas AG (2009) Diabetes Mellitus, Diagnosis and Pathophysiology. Tufts University; 2005-2009.

26. Sekikawa A, Tominaga M, Takahashi K, Eguchi H, Igarashi M, et al. (1993) Prevalence of diabetes and impaired glucose tolerance in Funagata area Japan. Diabetes Care 16: 570-574.

27. Ramachandran A, Snehalatha C, Latha E, Vijay V, Viswanathan M (1997) Rising prevalence of NIDDM in an urban population in India. Diabetologia 40 232-237.

28. Craig ME, Hattersley A, Donaghue KC (2009) Definition, epidemiology and classification of diabetes in children and adolescents. Pediatr Diabetes 10 Suppl 12: 3-12.

29. Cryer PE (2006) Mechanisms of sympathoadrenal failure and hypoglycemia in diabetes. J Clin Invest 116: 1470-1473.

30. Patidar D (2011) Pharmacology- III. (2ndedtn). Meerut: Shree Sai Prakashan $113-4$

31. Al Homsi MF, Lukic ML (1992) An Update on the pathogenesis of Diabetes Mellitus, Department of Pathology and Medical Microbiology (Immunology Unit) Faculty of Medicine and Health Sciences, UAE University, Al Ain, United Arab Emirates.

32. Hussain AN, Vincent MT (2007) Type 1 Diabetes Mellitus. 
Citation: Baynes HW (2015) Classification, Pathophysiology, Diagnosis and Management of Diabetes Mellitus. J Diabetes Metab 6: 541. doi:10.4172/2155-6156.1000541

Page 9 of 9

33. Raju SM, Raju B (2010) Illustrated medical biochemistry. 2nd Edition. Jaypee Brothers Medical Publishers Itd, New Delhi, India.

34. Holt RI (2004) Diagnosis, epidemiology and pathogenesis of diabetes mellitus: an update for psychiatrists. Br J Psychiatry Suppl 47: S55-63.

35. American Diabetes Association (2010) Diagnosis and classification of diabetes mellitus. Diabetes Care 33 Suppl 1: S62-69.

36. Mahler RJ, Adler ML (1999) Clinical review 102: Type 2 diabetes mellitus: update on diagnosis, pathophysiology, and treatment. J Clin Endocrinol Metab 84: 1165-1171.

37. Botero D, Wolfsdorf $\mathrm{JI}(2005)$ Diabetes mellitus in children and adolescents Arch Med Res 36: 281-290.

38. Cryer PE (2012) Minireview: Glucagon in the pathogenesis of hypoglycemia and hyperglycemia in diabetes. Endocrinology 153: 1039-1048.

39. Forbes JM, Cooper ME (2013) Mechanisms of diabetic complications. Physiol Rev 93: 137-188.

40. Harris MI, Klein R, Welborn TA, Knuiman MW (1992) Onset of NIDDM occurs at least 4-7 yr before clinical diagnosis. Diabetes Care 15: 815-819.

41. American Diabetes Association (2011) Standards of Medical Care in Diabetes-2011. Diabetes Care 34: S11-61.

42. Cox EM, Elelman D (2009) Test for screening and diagnosis of type 2 diabetes. Clin Diabetes 4: 132-138.

43. Gillett MJ (2009) International Expert Committee report on the role of the A1c assay in the diagnosis of diabetes: Diabetes Care 2009; 32(7): 1327-1334. Clin Biochem Rev 30: 197-200.

44. Selvin E, Steffes MW, Zhu H, Matsushita K, Wagenknecht L, et al. (2010) Glycated hemoglobin, diabetes, and cardiovascular risk in nondiabetic adults. N Engl J Med 362: 800-811.

45. Kolberg JA, Jørgensen T, Gerwien RW, Hamren S, McKenna MP, et al. (2009) Development of a type 2 diabetes risk model from a panel of serum biomarkers from the Inter99 cohort. Diabetes Care 32: 1207-1212.

46. Salomaa V, Havulinna A, Saarela O, Zeller T, Jousilahti P, et al. (2010) Thirtyone novel biomarkers as predictors for clinically incident diabetes. PLoS One 5: e10100.

47. American Diabetes Association (2012) Standards of medical care in diabetes-2012. Diabetes Care 35: 11-63.

48. Wagner EH, Austin BT, Davis C, Hindmarsh M, Schaefer J, et al. (2001) Improving chronic illness care: translating evidence into action. Health Aff (Millwood) 20: 64-78.

49. [No authors listed] (1998) Intensive blood-glucose control with sulphonylureas or insulin compared with conventional treatment and risk of complications in patients with type 2 diabetes (UKPDS 33). UK Prospective Diabetes Study (UKPDS) Group. Lancet 352: 837-853.
50. Ohkubo Y, Kishikawa H, Araki E, Miyata T, Isami S, Motoyoshi S, et al. (1995) Intensive insulin therapy prevents the progression of diabetic microvascular complications in Japanese patients with non-insulin-dependent diabetes mellitus: a randomized prospective 6-year study. Diabetes Res Clin Pract 28 103-117.

51. ADVANCE Collaborative Group, Patel A, MacMahon S, Chalmers J, Neal B et al. (2008) Intensive blood glucose control and vascular outcomes in patients with type 2 diabetes. N Engl J Med 358: 2560-2572.

52. ACCORD Study Group; ACCORD Eye Study Group, Chew EY, Ambrosius WT Davis MD, Danis RP, et al. (2010) Effects of medical therapies on retinopathy progression in type 2 diabetes. N Engl J Med 363: 233-244.

53. Ismail-Beigi F, Craven T, Banerji MA, Basile J, Calles J, et al. (2010) Effect of intensive treatment of hyperglycaemia on microvascular outcomes in type 2 diabetes: an analysis of the ACCORD randomised trial. Lancet 376: 419-430.

54. Shobana R, Augustine C, Ramachandran A, Vijay V (2005) Improving psychosocial care: The Indian experience. Diabetes Voice 50: 19-21.

55. Chew LD (2004) The impact of low health literacy on diabetes outcomes. Diabetes Voice 49: 30-32.

56. Coban E, Ozdogan M, Timuragaoglu A (2004) Effect of iron deficiency anemia on the levels of hemoglobin A1c in nondiabetic patients. Acta Haematol 112 126-128.

57. Whitmer RA, Karter AJ, Yaffe K, Quesenberry CP Jr, Selby JV (2009) Hypoglycemic episodes and risk of dementia in older patients with type 2 diabetes mellitus. JAMA 301: 1565-1572.

58. de Galan BE, Zoungas S, Chalmers J, Anderson C, Dufouil C, et al. (2009) Cognitive function and risks of cardiovascular disease in hypoglycaemia in patients with type 2 diabetes: the Action in Diabetes and Vascular Disease: Preterax and Diamicron Modified Release Controlled Evaluation (ADVANCE) trial. Diabetologia 52: 2328-2336

59. Stumvoll M, Goldstein BJ, van Haeften TW (2005) Type 2 diabetes: principles of pathogenesis and therapy. Lancet 365: 1333-1346.

60. Hermansen K, Mortensen LS, Hermansen ML (2008) Combining insulins with oral antidiabetic agents: effect on hyperglycemic control, markers of cardiovascular risk and disease. Vasc Health Risk Manag 4: 561-574.

61. Kroon L, Goldfine ID, Tanyolac S (2010) Insulin - Pharmacology, Types of Regimens, and Adjustments. Insulin -"Pharmacology, Types of Regimens, and Adjustments .

62. Riddle MC (2005) Glycemic management of type 2 diabetes: an emerging strategy with oral agents, insulins, and combinations. Endocrinol Metab Clin North Am 34: 77-98 